\title{
Assessment of Donkey Utilization Practices and Challenges in Hossana City of Ethiopia
}

\author{
Haftu Kebede Sebho* and Adane Haile K \\ Department of Animal Sciences, Wachemo University, Ethiopia
}

Submission: May 07, 2018; Published: May 25, 2018

"Corresponding author: Haftu Kebede Sebho, Department of Animal Sciences, College of Agricultural Sciences, Wachemo University, P.0. Box 667, Hossana, Ethiopia, Email: Haftuk2001@gmail.com

\begin{abstract}
The study was conducted on 120 randomly selected male working donkeys and their owners with the objective of assessing utilization practice and the general management problems of working donkeys in Hossana city (Ethiopia). Relevant information was collected by semistructured and pretested interview schedule and direct physical observation of the animals. In the study area donkeys provide cart services, carrying different kinds of commodities weighing more than $400 \mathrm{~kg}$ to get high benefit in short time and covering distances of more than $5 \mathrm{~km}$ for duration of more than 7 hours and use more than 6 day per week. The life span of working donkeys in the present study area were less than 5 year, between 6-10 year and more than 11 year with a percentage of $29.2 \%, 35.8 \%$ and $35 \%$, respectively. The wound prevalence in the present study area was $56.7 \% .31 .7 \%$ of owners take diseased donkey to government veterinary, $27.5 \%$ take diseased donkey to private veterinary and $14.2 \%$ used traditional treatment. Harnessing problems $\left(1^{\text {st }}\right)$, diseases $\left(2^{\text {nd }}\right)$, over loading $\left(3^{\text {rd }}\right)$, injury $\left(4^{\text {th }}\right)$, lack of veterinary service $\left(5^{\text {th }}\right)$, were found to be the top challenges in the area. Friends and relatives $\left(1^{\text {st }}\right)$ neighbors $\left(2^{\text {nd }}\right)$ own experience $\left(3^{\text {rd }}\right)$ NGOs $\left(4^{\text {th }}\right)$ extension agents $\left(5^{\text {th }}\right)$ and reading materials $\left(6^{\text {th }}\right)$ were found the main source of knowledge on donkey utilization. Therefore, awareness creation about how to handle animals to avoid physiological stress due to over working, over loading and harmful effect of certain management practice should be conducted through government and non-government organization.
\end{abstract}

Keywords: Donkey; Ethiopia; Hosanna city; Practices; Utilization

\section{Introduction}

Ethiopia has the largest population of donkeys in Africa and the second largest donkey population in the world after [1]. It is estimated that the world donkey population is about 44 million; half is found in Asia, just over one quarter in Africa and the rest mainly in Latin America [2]. Ethiopia is a country with one of the highest donkey populations in the world. The total number is estimated about 6.95 million donkeys and in the highlands farmers own an average of 2-3 donkeys per family [3,4]. Although donkeys are found in all the ecological zones of the country the majority are found in the highlands [4]. In all zones of Ethiopia, donkeys offer the only realistic way of obtaining returns from agriculture above mere existence as pack animals. The increasing human population, demands for transport of goods to and from far, remote areas and construction activities around towns are making equines highly demanded animals [5].

Draught animals along with humans provide an estimated $80 \%$ of the power input on farms in developing nations [6] but animals often suffer from maltreatment, overloading and ill feeding during no work period [7]. Since these animals are working animal, they are always expected that they may undergo suffering in day to day life due to stress, strain due to overwork, tiredness due to working with poor health, feed and drinking water. Non availability of proper veterinary care, working under hot and dusty environment, lack of proper management, walking long distances and overloading, poor handling during loading, poor harness devices and unloading is common [8].

In Ethiopia, the use of donkeys for transportation will continue for years to come because of the rugged terrain characteristics inaccessible for modern road transportation facilities as well as the absence of well-developed modern transport networks and the prevailing low economic status of the community. Despite their invaluable contributions, equines in Ethiopia are the most neglected animals, accorded low social status [5]. Working donkeys are prone to painful, debilitating and often fatal tropical illnesses conditions. In addition, these animals work under difficult environmental conditions including intense heat, difficult terrain and often inappropriate equipment, with inadequate food and water, resulting in exhaustion, dehydration, malnutrition, lesions and hoof problems [9]. 
Constraints such as poverty and lack of knowledge mean that animal welfare is being compromised internationally. When working donkeys can no longer work, the owners lose their livelihoods, either temporarily or permanently. The management of working donkeys in developing countries is therefore crucially important, not only for the health and survival of those animals, but also for the livelihoods of those people dependent on them [10]. So far there is no information on donkey utilization, management and constraints affecting them in the area and such information would be useful for designing strategies that will help to improve donkey utilization. Therefore, the objectives of the study were to document the utilization practice and constraints affecting working donkey found in Hossana city.

\section{Materials and Methods \\ Description of study area}

The present study was carried out in Hossana city of Hadiya Zone Southern Nations National Regional State of Ethiopia in the year 2014/15. The town consists of 8 kebele's (Arada, Betel, Bobicho, Heto, Lichamba, Melamba, Narramo and Sechduna) which are the smallest administrative units in Ethiopia. The study area found at a distance of $212 \mathrm{~km}$ from the Regional city and $232 \mathrm{~km}$ from the capital, Addis Ababa. The area receives an average annual rainfall of $1001-1200 \mathrm{~mm}$ and temperature ranges from $15.1-20^{\circ} \mathrm{C}$. The pack animals used in the city area of these places mainly kept for transportation of construction materials, firewood, farm produce, water and sugar cane mainly hitched on cart or loaded on their back.

\section{Data collection and sampling procedure}

A cross-sectional study was conducted on one hundred twenty (120) randomly selected male working donkeys. Relevant information was collected by semi-structured and pretested interview schedule by personal interviewing of respondents and direct physical observation of the animals like wound/physical injuries, joint abnormalities, skeleton abnormalities, growth of hooves, fit of harness and their gait.

\section{Questionnaire survey}

Each randomly selected donkey owner was interviewed with a semi-structure interview (having both open and close questions)to extrapolate information regarding owner's general information, donkey management practice (harnessing, feeding, housing, health care), working nature (duration of work, weight carried, length of journey covered, nature of working environment) and donkey-owner relationship.

\section{Physical examination}

In addition to the survey, work each randomly selected donkey was physically observed for any external body injury and findings including wound/physical injuries, joint abnormalities, skeleton abnormalities, growth of hooves and gait were recorded on sheet either as present/absent. The examination was carried out at the working site during daytime.

\section{Data analysis and presentation}

Data both from the direct physical observation and questionnaire were properly coded and entered into MicrosoftExcel-2007 spread sheet. The data was filtered for any invalid entry and then transferred to SPSS 16.0 version for windows package (2007) for statistical analysis. Descriptive statistics such as frequency and percentage were used to analyze the data.

\section{Result and Discussion}

\section{Socio-economic characteristics of donkey owners}

The general variables associated with donkey keeper respondents are distributed by sex, age, marital status, and educational status are presented in Table 1.Out of a total 120 respondents $98.3 \%$ were female. The study also showed that $53.3 \%$ of the household head were married while the remaining $46.7 \%$ were single. The majority age of the respondents were $<30$ years $(81.7 \%)$ This result showed that people in the most productive age are actively engaged in cart pulling. Concerning educational status $44.2 \%$ of respondents had elementary school education, $24.2 \%$ could read and write and only $20.8 \%$ had high school education.

Table 1: General characteristics of respondents.

\begin{tabular}{|c|c|c|}
\hline Category & Variable & Percentage $(n=120)$ \\
\hline \multirow{2}{*}{ Sex } & Male & $98.3(118)$ \\
\hline & Female & $1.7(2)$ \\
\hline \multirow{2}{*}{ Marital status } & Married & $53.3(64)$ \\
\hline & Single & $46.7(56)$ \\
\hline \multirow{4}{*}{ Age } & $<30$ & $81.7(98)$ \\
\hline & $31-40$ & $17.5(21)$ \\
\hline & $41-50$ & $0.8(1)$ \\
\hline & $>51$ & - \\
\hline \multirow{5}{*}{ Educational level } & Illiterate & $9.2(11)$ \\
\hline & Read and write & $24.2(29)$ \\
\hline & Elementary school & $44.2(53)$ \\
\hline & High school & $20.8(25)$ \\
\hline & Diploma and above & $1.7(2)$ \\
\hline
\end{tabular}

Value in bracket $=$ frequency

\section{Practices of respondents on donkey utilization}

Data collected on the traditional management system (watering, feeding, feet trimmed and health care) of donkey, indicated that all animal owners do provide water and feed to donkey at home, most were known to provide rest to donkey (66.7\%). Majority (63.3\%) of the respondents trimmed the feet of their donkeys. Most of the respondents (90.8\%) had good attitude towards working donkey as shown in Table 2. This 
observation was disagree with [11] described most respondents had poor attitude on working equine in and Around Nekemte Town, East Wollega Zone.

Table 2: Respondents practice on donkey management

\begin{tabular}{|c|c|c|}
\hline Activity & Response & Percentage \\
\hline \multirow{2}{*}{ Provide feed and water } & Yes & $100(120)$ \\
\hline & No & - \\
\hline \multirow{2}{*}{ Loaded fair load } & Yes & $91.7(110)$ \\
\hline & No & $8.3(10)$ \\
\hline \multirow{2}{*}{ Donkey health care } & Yes & $95.8(115)$ \\
\hline & No & $4.2(5)$ \\
\hline \multirow{2}{*}{ Giving rest to donkey every day? } & Yes & $66.7(80)$ \\
\hline & No & $33.3(40)$ \\
\hline \multirow{2}{*}{ Cleaning of house regularly } & Yes & $86.7(104)$ \\
\hline & No & $13.3(16)$ \\
\hline \multirow{2}{*}{ Trimmed feet of donkey } & Yes & $63.3(76)$ \\
\hline & No & $36.7(44)$ \\
\hline \multirow{2}{*}{$\begin{array}{l}\text { Opinions/Attitudes of respondents on } \\
\text { donkey utilization }\end{array}$} & High & $90.8(109)$ \\
\hline & Low & $9.2(11)$ \\
\hline
\end{tabular}

Value in bracket $=$ frequency

\section{Respondents practice related to treatment of disease in donkeys}

Table 3 shows the data related to health care management. In case of serious illness the higher proportion (31.7\%) of owners mostly treated their animals by taking them to the government veterinary centers, private veterinary $(27.5 \%)$ or traditional treatment (14.2\%).This is in line with the report of [12] who concluded that animals were mostly treated by veterinarians. However, which doesn't be similar to the findings of [13] where they found that the animals were mostly treated by traditional medicine without the help of registered veterinarian's in Southern Ethiopia. However, the present result agrees with the findings of [14] where he found that $31.6 \%$ of the diseased donkeys were taken to the nearby veterinary clinics and 10.5 $\%$ were treated traditionally in mekelle city. Based on Figure 1 , the study revealed that majority of respondents considered loss of donkey by disease to be a moderately serious problem. Table-3 also gives data regarding feeding practices followed by animal owners. Both roughage and concentrate were provided by almost (45\%) owners but subject to availability, price and without any scientific considerations. The present data agrees with the findings of [13] where he found that all equines were provided available feed, mainly grass and few cereal by-products in southern Ethiopia.
Table 3: Distribution of respondents according to healthcare and feeding practices.

\begin{tabular}{|c|c|c|}
\hline Category & Activity & Percent \\
\hline \multirow{7}{*}{$\begin{array}{l}\text { Access of diseased } \\
\text { donkey to treatment }\end{array}$} & $\begin{array}{c}\text { Take to government } \\
\text { veterinary }\end{array}$ & $31.7(38)$ \\
\hline & Take to private veterinary & $27.5(33)$ \\
\hline & Use traditional treatment & $14.2(17)$ \\
\hline & $\begin{array}{l}\text { Take to Gov. \& private } \\
\text { veterinary }\end{array}$ & $9.2(11)$ \\
\hline & $\begin{array}{l}\text { Take to Gov. \& use } \\
\text { traditional treatment }\end{array}$ & $2.5(3)$ \\
\hline & $\begin{array}{l}\text { Take to private \& use } \\
\text { traditional treatment }\end{array}$ & $7.5(9)$ \\
\hline & Use all the above three & $7.5(9)$ \\
\hline \multirow{2}{*}{$\begin{array}{l}\text { Working injured/ } \\
\text { diseased animal }\end{array}$} & Yes & $16.7(20)$ \\
\hline & No & 83.3(100) \\
\hline \multirow{3}{*}{$\begin{array}{l}\text { Type of feed access to } \\
\text { working donkey }\end{array}$} & Roughage/crop residue & $27.5(33)$ \\
\hline & Concentrate & $27.5(33)$ \\
\hline & $\begin{array}{l}\text { Both roughage and } \\
\text { concentrate }\end{array}$ & $45(54)$ \\
\hline
\end{tabular}

Value in bracket $=$ frequency

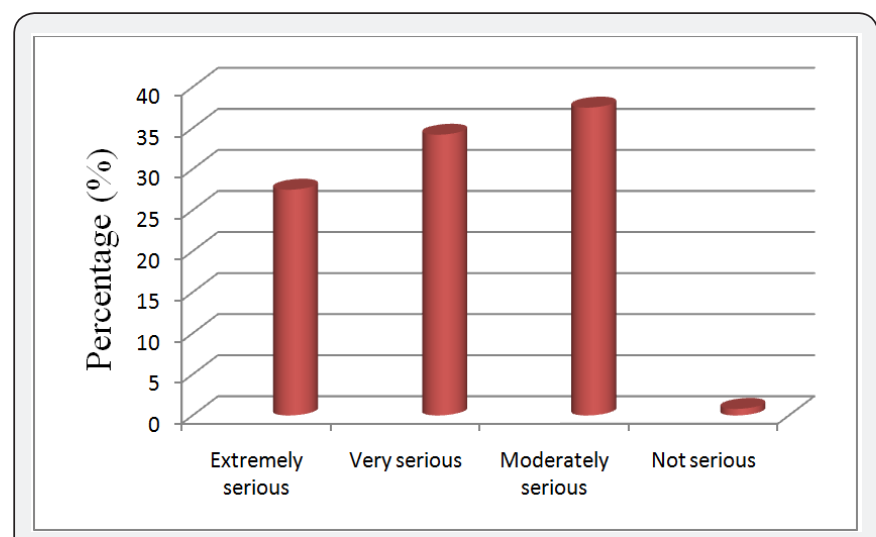

Figure 1: Awareness on the seriousness of loss of donkey by disease.

\section{Working practice of donkey}

Most (55\%) of the donkeys worked for more than 6 days followed by (39.2\%) range 3-6 days/ week. Majority (51.7\%) of the respondents replied that numbers of hours of work per day were more than 7 hours followed by (40.8\%) range between 4-7 hours. This is in line with [5] who noted that donkey work from 4 to 12 hours/day in Ethiopia, depending on the season and type of work. Data concerning loading practices most (60.8\%) of the donkey carried more than $401 \mathrm{~kg}$ load at a time (Table 4). Most $(92.5 \%)$ of the respondents indicated that they packing heavy load in order to get high benefit in short time. $35.8 \%$ of the respondents replied that distance worked per use were more than more than $5 \mathrm{~km}$. The result obtained in this study was higher than the result reported by [5] carrying an average weight load of 150 
kg but they travel as far as $70 \mathrm{~km} /$ day in Hawassa. Similarly this observation was in agreement with [11] described overloading and over working was the main constraint on working equine in and around nekemte town. While interviewing, owners also expressed that majority (35.8\%) life span of working donkey were varies between 6-10 year (Table 4). The present finding was not in agreement with the findings of [15] who stated that the life expectancy is up to 30 years.

Table 4: Distribution of respondents in respect to practices related to frequency of use/week amounts of load, reason of packing heavy load and Life span of working donkey.

\begin{tabular}{|c|c|c|}
\hline Criteria & Activity & $\begin{array}{l}\text { Percent } \\
(n=120)\end{array}$ \\
\hline \multirow{3}{*}{ Frequency of use/week } & $<3$ day & $5.8(7)$ \\
\hline & 3-6day & $39.2(47)$ \\
\hline & $>6$ day & $55(66)$ \\
\hline \multirow{3}{*}{ No. of hours worked/day } & $<4$ hours & $7.5(9)$ \\
\hline & 4-7hours & $40.8(49)$ \\
\hline & $>7$ hours & $51.7(62)$ \\
\hline \multirow{3}{*}{ Life span of working donkey } & $<5$ year & $29.2(35)$ \\
\hline & 6-10year & $35.8(43)$ \\
\hline & $>11$ year & $35(42)$ \\
\hline \multirow{4}{*}{ Estimated amounts of load } & $<100 \mathrm{~kg}$ & $0.8(1)$ \\
\hline & $100-300 \mathrm{~kg}$ & $20.8(25)$ \\
\hline & $301-400 \mathrm{~kg}$ & $17.5(21)$ \\
\hline & $>401 \mathrm{~kg}$ & $60.8(73)$ \\
\hline \multirow{4}{*}{ Distance covered per use } & $<2 \mathrm{~km}$ & $11.7(14)$ \\
\hline & $2-4 \mathrm{~km}$ & $33.3(40)$ \\
\hline & 4- $5 \mathrm{~km}$ & $19.2(23)$ \\
\hline & $>5 \mathrm{~km}$ & $35.8(43)$ \\
\hline \multirow{4}{*}{ Reason of carting heavy load } & $\begin{array}{c}\text { To get high } \\
\text { benefit in short } \\
\text { time }\end{array}$ & $92.5(111)$ \\
\hline & Lack of awareness & $4.2(5)$ \\
\hline & Carelessness & $2.5(3)$ \\
\hline & $\begin{array}{c}\text { To get high } \\
\text { benefit in short } \\
\text { time \& Lack of } \\
\text { awareness }\end{array}$ & $0.8(1)$ \\
\hline
\end{tabular}

\section{Source of information on donkey utilization and major constraints affecting working donkeys}

Information is the key for success in management and husbandry practices of agricultural activities in general [16]. Though various institutions are attempting to supply the information necessary, inability to source accurate, timely and easily accessible information, presents several challenges to producers [17]. In the present study each respondent was requested to rank their source of information on donkey utilization, reason of keeping donkey and challenges of working donkey practice (Table 5). Accordingly, the most important constraints of working donkey in the study areas were harnessing problems $\left(1^{\text {st }}\right)$, disease $\left(2^{\text {nd }}\right)$, over loading $\left(3^{\text {rd }}\right)$, injury $\left(4^{\text {th }}\right)$, lack of veterinary service $\left(5^{\text {th }}\right)$, were found to be the top challenges in the area (Table 5). This agrees with [14] who reported that the major constraints of donkeys in mekelle city were lack of management, harnessing problem, overloading and over working, disease and veterinary services and nutritional problem respectively.

Table 5: Reason of keeping donkey and source of information (knowledge) on proper utilization

\begin{tabular}{|c|c|}
\hline Source of knowledge & Rank (\%) \\
\hline Friends and relatives & $1(38.3)$ \\
\hline Neighbors & $2(31.7)$ \\
\hline Reading materials & $6(49.2)$ \\
\hline Own experience & $3(31.7)$ \\
\hline NGOs & $4(36.7)$ \\
\hline Extension agents & $5(36.7)$ \\
\hline Reason of keeping donkey & \\
\hline As cart animals & $1(90.8)$ \\
\hline Ploughing & $3(36.7)$ \\
\hline Breeding /commercial sales & $2(41.7)$ \\
\hline Status & $4(28.3)$ \\
\hline Major constraints of donkey & \\
\hline Harnessing problems & $1(39.2)$ \\
\hline Over loading & $3(20.8)$ \\
\hline Disease & $2(42.5)$ \\
\hline Lack of veterinary service & $5(36.7)$ \\
\hline Injury & $4(37.5)$ \\
\hline
\end{tabular}

Value in bracket $=$ percent

Regarding to the source of knowledge friends and relatives $1^{\text {st }}$, neighbors $2^{\text {nd }}$, own experience $3^{\text {rd }}, \mathrm{NGOs} 4^{\text {th }}$, extension agents $5^{\text {th }}$ and reading materials $6^{\text {th }}$ were found to be the top source. The most important reasons given for keeping donkey as cart animals were ranked high (90.8\%) (Table 5).This might be due to the cheaper price of the animal. This finding was in agreement with studies by [18] in northern Tanzania, [19] in Ethiopia, [20] in Turkana and Samburu pastoralist societies, in Kenya and [21] in South Africa, kept donkeys mainly for pack servicesrespectively.

\section{Physical observations of health parameters}

Upon physical observation, working donkeys showed abnormality in skeleton (18.3\%), abnormality in joints $(25.8 \%)$ and abnormal in way of walking (20\%). Hooves were subjectively assessed for lesions and extent of growth. Majority (75\%) 
hooves growths were found normal, except 2.5\% lesions. Upon physical examination, pack animals showed abnormality in eyes, abnormality in gait, back lesions, girth lesions, limb deformity and tether lesions. The overall prevalence of wound in working donkeys was $56.7 \%$ (Table 6). The result obtained in the present study was clearly lower than $77.5 \%$ in Ethiopia reported by [22] and $79.4 \%$ in Hawassa by [5] but closer to 59\% in Jordan reported by [23] and 54\% in Morocco reported by [24], However lower than the report by [25] (40\%) in central Ethiopia. the higher prevalence of wound in working donkeys in the present study might be due to more exposure to work, poor harnessing and carrying heavy load over a long distance for hours. Most donkey owners though answered the interview schedule but some owners were unwilling to answered the interview and collect data this may be due to some unthinkable or fear.

Table 6: Prevalence of poor physical health parameters based on 120 donkeys observed in Hossana town.

\begin{tabular}{|c|c|}
\hline Source of Knowledge & Rank (\%) \\
\hline Friends and relatives & $1(38.3)$ \\
\hline Neighbors & $2(31.7)$ \\
\hline Reading materials & $6(49.2)$ \\
\hline Own experience & $3(31.7)$ \\
\hline NGOs & $4(36.7)$ \\
\hline Extension agents & $5(36.7)$ \\
\hline Reason of keeping donkey & \\
\hline As cart animals & $1(90.8)$ \\
\hline Ploughing & $3(36.7)$ \\
\hline Breeding /commercial sales & $2(41.7)$ \\
\hline Status & $4(28.3)$ \\
\hline Major constraints of donkey & \\
\hline Harnessing problems & $1(39.2)$ \\
\hline Over loading & $3(20.8)$ \\
\hline Disease & $2(42.5)$ \\
\hline Lack of veterinary service & $5(36.7)$ \\
\hline Injury & $4(37.5)$ \\
\hline
\end{tabular}

Value in bracket $=$ frequency

\section{Conclusion and Recommendation}

This study offers preliminary findings from an investigation into the welfare of working donkeys in Hossana town, Ethiopia and provides baseline information to inform future research and strategies to enhance donkey well-being. In the study area donkey are widely used for cart pulling or as pack animals for transport of vegetables and fruits to the market place, transportation of animal food from and to the market, building materials, fire woods and grains to flour mill. In spite of varied uses of donkey in the study area, they are confronted by series of physical injuries; abused by beating and harming, over loading, over working, unnecessarily neglected and general mal treatment and drenching traditions are still prevalent health problems.
Most of the animal owners are not even aware of animal welfare practices; as a result animals have to undergo significant suffering due to improper handling, transport and husbandry practices. Therefore, awareness creation about the importance, how to handle animals to avoid physiological stress due to over working, over loading and harmful effect of certain management practice should be conducted through government and non-government organization. Hence, implementing a comprehensive donkey health and welfare improvement program should be a priority for concerned stakeholder.

\section{Acknowledgements}

The authors are grateful to the animal owners of the study area, for giving us valuable information and allow us to physical examination of the donkey.

\section{References}

1. China Anon (2007) FAO Statistical Database Website. Food and Agricultural Organization of the United Nations.

2. Fielding D, Starkey P (2004) Donkeys, people and development A resource book in the animal Traction Network for Eastern and Southern Africa (ATNESA), ACP-EU Technical Centre for Agricultural and Rural Cooperation (CTA), Wageningen, The Netherlands.

3. Gebreab F, Fielding D, Starkey P (2004). Donkey Utilisation and Management in Ethiopia. Donkeys, People and Development. A esource book in the Animal Traction Network for Eastern and Southern Africa (ATNESA). ACP-EU Technical Centre for Agricultural and Rural Cooperation (CTA).

4. CSA (2014) Central Statistical Agency, Agricultural sample survey. Report on livestock and livestock characteristics 236: 11-15.

5. Biffa D, Woldemeskel M (2006) Causes and Factors Associated With Occurrence of External Injuries in Working Equines in Ethiopia. Inter J App Res Vet Med 4(1): 1-7.

6. Pearson RA (2005) Contributions to Society: Draught and Transport. Encyclopedia of Animal Science. Marcel Dekker Inc, USA, pp: 248-250.

7. Swarup D (2007) Current status of animal welfare in India: issues and options. Short course on "Animal behavior and Welfare" under CAS in Veterinary Physiology, IVRI, pp: 23-27.

8. Anonymous (2007) Report of the working group on Animal Husbandry and Dairying for the Eleventh Five Year plan (2007-2012). Planning commission-6 pp: 110.

9. Brooke (2007) Bearing a Heavy Burden.

10. Pearson RA, Krecek RC (2006) Delivery of health and husbandry improvements to working animals in Africa. Tropical Animal Health and Production 38(2): 93-101.

11. Morka A, Adisalem H, Bojia E, Eyob H, Bedasso M (2014) Health and Welfare Assessment of Working Equine in and Around Nekemte Town, East Wollega Zone, Ethiopia. American-Eurasian Journal of Scientific Research 9 (6): 163-174.

12. Biswas P, Dutt T, Patel M, Kamal R, Bharti PK, et al. (2013) Assessment of pack animal welfare in and around Bareilly city of India. Vet World 6(6): 332-336.

13. Mekuria S, Abebe R(2010) Observation on major welfare problems of equine in Meskan district, Southern Ethiopia. Livestock Research for Rural Development. 
14. Kumar Niraj, Fisseha KK, Shishay N, Hagos Y (2014) Welfare Assessment of Working Donkeys in Mekelle City, Ethiopia. Global Veterinaria 12(3): 314-319.

15. Fred O, Pascal K (2006) Extension Approaches to improving the welfare of working equines. Kenya Network for Dissemination of Agricultural Technologies (KENDAT). Nairobi, Kenya, pp: 1-28.

16. Hassan MS, Yassin SM, Mohamed HAS, Othman MS, Samah BA, et al (2011) Receiving the Agriculture Information through Mass Media and Interpersonal Sources among the Rural Community. American J Agric Bio Sci 6(3): 451-461.

17. Jack BK (2013) Constraints on the adoption of agricultural technologies in developing countries. Literature review, Agricultural Technology Adoption Initiative, J-PAL (MIT) and CEGA (UC Berkeley).

18. Swai ES, Bwanga SJR (2008) Donkey keeping in northern Tanzania: socio-economic roles and reported husbandry and health constraints. Livestock Research for Rural Development 20(5).

19. Admassu B, Shiferaw Y (2011) Donkeys, horses and mules-their contribution to people's livelihoods in Ethiopia. The Brooke 2011 Addis Ababa, Ethiopia.
20. Twerda M, Fielding D, Field C (1997) Role and management of donkeys in Samburu and Turkana pastoralist societies in northern Kenya. Tropical Animal Health Production 29(1): 48-54.

21. Wells D, Krecek RC (2001) Socio-economic, health and management aspects of working donkeys in Moretele 1, North West Province, South Africa. Journal of South African Veterinary Association 72(1): 37-43.

22. Curran M, Feseha G, Smith D (2005) The impact of access to animal health services on donkey health and livelihoods in Ethiopia. Tropical Animal Health and Production 37(1): 47-65.

23. Burn CC, Pritchard J, Farajat M, Twaissi A, Whay R (2007) Risk factors for strap-related lesions in working donkeys at the World Heritage Site of Petra in Jordan. Veterinary Journal 178(2): 263-271.

24. Sells P, Pinchbeck G, Mezzane H, Ibourki J, Crane M (2010) Pack wounds of donkeys and mules in the Northern High Atlas and lowlands of Morocco. Equine Veterinary Journal 42(3): 219-226.

25. Pearson RA, Mengistu TA, Agajie EF, Allanand DG, Smith MA (2002) Use and Management of Donkeys in Peri-Urban Areas of Ethiopia. Centre for Tropical Veterinary Medicine; Draught Animal Power Technical Report, 5 2001, ISBN: 0-907146-13-9.

\section{Your next submission with Juniper Publishers} will reach you the below assets

- Quality Editorial service

- Swift Peer Review

- Reprints availability

- E-prints Service

- Manuscript Podcast for convenient understanding

- Global attainment for your research

- Manuscript accessibility in different formats

(Pdf, E-pub, Full Text, Audio)

- Unceasing customer service

Track the below URL for one-step submission https://juniperpublishers.com/online-submission.php 